\title{
Saint Guinefort Addressing Thomas Aquinas's Shadow
}

Marie-Madeleine van Ruymbeke Stey, Ph.D

Capital University

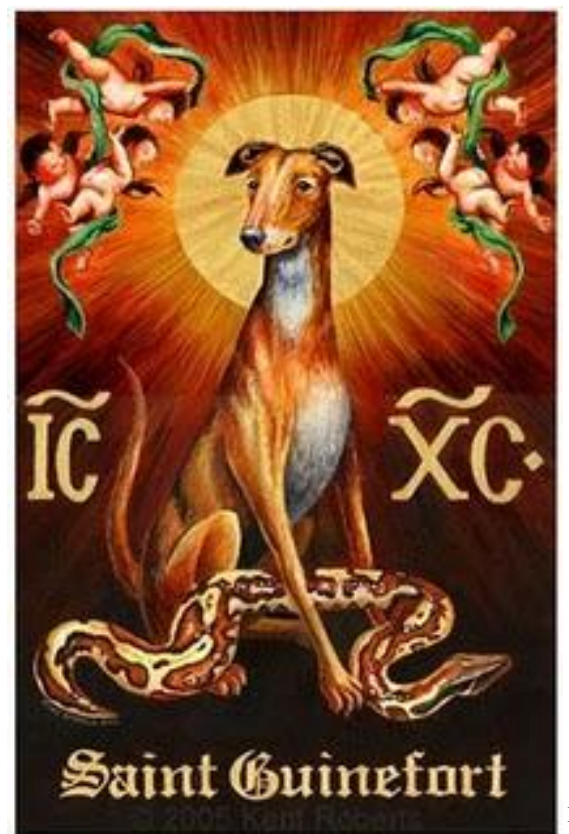

In 1250, in one of his Exempla, the French monk and inquisitor Etienne de Bourbon describes a strange cult he had found in the Dombes, a poor agricultural region North of Lyon in France. In confession, he had heard many women who acknowledged that they had prayed to St Guinefort, Martyr. Upon inquiring about this saint unknown to him, de Bourbon discovered that Guinefort was a dog killed by his master, a knight who mistakenly thought that the dog had devoured his baby. Actually, after killing Guinefort, the knight found his baby safe, lying next to the dead body of a large snake. The master understood then that he had killed his baby's savior, and ashamed of himself, he threw the dog's body in a well and covered it with stones. 
The castle was in due course destroyed by divine will, and the land reduced to a desert abandoned by its inhabitants. The local peasants, hearing of the dog's noble deed and innocent death, began to visit the place and honor the dog as a martyr in quest of help for their sicknesses and other needs. . . . . Women especially, with sick or poorly children, carried them to the place. (http://www.fordham.edu/halsall/source/guinefort.html)

The theme of an animal saving a baby from death, also found in the Anglo-Saxon legend of Gelert as described by Bering-Gould dates back to the Sanskrit literature of India, and Jean-Claude Schmitt, a French folklorist who has researched the motif extensively, points out that it is first found in the $6^{\text {th }}$ century BC Panchatantra, a treatise on the education of princes (63). There, a pet mongoose saves the family baby from a snake but is mistakenly killed by its mistress. In order to explain the recurrence of the theme of the faithful animal, Schmitt's suggests two possibilities: the theory of the migration of the fables, or the existence of a group of Indo-European peasant legends (98). After describing the rite observed at $\mathrm{St}$ Guinefort's shrine, Schmitt concludes that it is similar to any rite dealing with "changelings," in which mothers try to recuperate their own healthy babies who were thought to have been abducted by evil spirits and replaced by the spirits' sickly children (109). Schmitt further attributes the holy dog's name to the confusion with a Saint Guinefort from Pavia in Italy since monks from the Cluny Abbey had ties with Pavia and had been in the Dombes area in the middle of the $12^{\text {th }}$ century establishing relations between their abbey and the peasants (144-147).

However, those historical circumstances do not justify the $13^{\text {th }}$ century French peasants pious canonization of a dog, an event unique in Christian history, nor do they explain why the holy dog was prayed to throughout six centuries. I will address these questions in two stages. I will first consider why the French peasants included a dog among the Christian saints, and finally why they attributed healing powers to him.

Jung explains that the theme of the helpful animal is very frequent in folk tales, where the animal often are more intelligent and more knowledgeable than humans ( CW, IX, 1: 231), or even morally superior:

In certain respects the animal is superior to man. It has not yet blundered into consciousness nor pitted a self-willed ego against the power from which it lives: on the contrary, it fulfills the will that actuates it in a well-nigh perfect manner. Were it conscious, it would be morally better than man. ( CW, IX, 1: 230)

Indeed, St Guinefort's martyrdom clearly establishes him far above his master whose behavior had been so improvident. 


\section{Stey}

Why did French peasants canonize a dog in that precise area, at that exact period? A brief look at the Christian climate in the area is revealing. On the one hand, the people participated in the Albigensian and the Waldensian heresies as well as the cult of St Guinefort. ${ }^{2}$ On the other hand, the Catholic Church organized the Crusade against the Albigenses, created the Inquisition and taught the philosophy of Thomas Aquinas. Aquinas, deeply influenced by Aristotle, wrote as follows: "The Divine Ordinance of animals and plants is preserved not for themselves but for man...As Augustine says...both their life and their death are subject to our use.” Quoting Aristotle almost exactly, Aquinas adds: “...Dumb animals and plants are devoid of the life of reason ...a sign of which is that they are naturally enslaved and accommodated to the uses of others..." (Linzey 13) Andrew Linzey, in his book Animal Theology, makes an interesting argument for my point of view when he qualifies Aristotle, Augustine and Aquinas as "Aristocrats of the Mind" (10-12). Carl Jung had already expressed the same opinion: "The Aristotelian intellectualism of St. Thomas appeared to me more lifeless than a desert ... They want to prove a belief to themselves, whereas actually it is a matter of experience" (Memories 69). He goes further still: "God Himself had disavowed theology and the Church founded upon it" (Memories 93). Not surprisingly, while the official Church was becoming more and more "aristocratic", a "people's church" developed in reaction. Even if Schmitt sees in Guinefort's cult the peasantry's response to its oppression by the nobility and the Church (223-225), I understand it as a natural and healthy resistance to the Church dehumanizing intellectualism. The canonization of Guinefort becomes then a means of addressing the Church's shadow: the intellectualism, which killed symbol and transformed a living relation with the godhead into a rational demonstration. As the French Church submitted more and more to the influence of Thomas Aquinas, Guinefort's cult was a reminder that religion is about life and psyche. As the Catholic Church's concerns were becoming farther removed from the peasants' everyday lives and worries, the peasants turned to St Guinefort. Like them, Guinefort had simply been faithful, risking his own life to protect his master's child. However, his efforts were not appreciated and, like the peasants, he was treated with harsh ingratitude. Nonetheless, God was with him: the proof is that the castle of Guinefort's master "was in due course destroyed by divine will, and the land reduced to a desert abandoned by its inhabitants" (Schmitt 95-96).

God has avenged Saint Guinefort, Martyr, and maybe the French peasantry hoped God would avenge them too. In the meantime, however, they counted on Guinefort to heal them. Environmentalist Paul Shepard explains how exaltation of humankind produces anxiety; he writes: "The anguish of our human tragedy is due more to a delusional system that insists on the exaltation of our species and failed 
myths of progress and history than to reality (Tender 33). So, in canonizing Guinefort, French peasants had found instinctively how to address the anxiety produced by the Church's intellectualism.

Today, philosophy and even science condemn the glorification of human intellect and human race. In a recent book, Paul Shepard speaks out very strongly: "Our modern myths of Faustian Historical Man and monotheistic hubris are . . . chosen exile into a fantasy world of man-the-conqueror" (The Others 7). Indeed, the canonization of a dog was the perfect answer to Aquinas' "exaltation of our species." In the same vein, philosopher Mary Midgley criticizes human pride and attests to the importance of animals:

The topic ... is much bigger than it may seem. It bears on many central themes of political and general philosophy... Our tradition of thought has ... left a surprising gap...This has damaged our reasoning right across this alarming range of subjects. (Animals 7)

Shepard as well as Midgley affirms clearly that Aristotle, Augustine and Aquinas's scorn for animals and exaltation of the human intellect has harmed us psychologically and philosophically.

Today, even science and philosophy distrust the power of the reason and intellect by themselves. The late $20^{\text {th }}$ century and the $21^{\text {st }}$ are rediscovering the importance of animals. Paul Shepherd showed how animals contributed to our own development. According to him, the humans species cannot be fully itself without animals. He writes:

There is a profound, inescapable need for animals that is in all people everywhere, an urgent requirement for which no substitute exists. It is no vague, romantic, or intangible yearning, no simple sop to our loneliness for Paradise. It is as hard and unavoidable as the compounds of our inner chemistry. It is universal but poorly recognized. (Thinking 2)

Shepard argues that the evolution of human intellect was made possible by man's interaction with animals. He shows that humans evolved by watching other animal species, observing and imitating their behavior.

It is the peculiar way that animals are used in the growth and development of the human person, in those most priceless qualities which we lump together as "mind" ... Animals are among the first inhabitants of the mind's eye. They are basic to the development of speech and thought. Because of their part in the growth of consciousness, they are inseparable from a series of events in each human life, indispensable to our becoming human in the fullest sense. (Thinking 2) 


\section{Stey}

Carl Jung had already insisted on the importance of animals. He loved animals and explains how much, as a medical student, he hated physiology because of vivisection:

My compassion for animals ...rested on the deeper foundation of a primitive attitude of mind-on an unconscious identity with animals ...At the time, of course, I was wholly ignorant of this important psychological fact." (Memories 101)

Elsewhere, Jung explains "this important psychological fact" : the animal represents the archetype of the spirit (CW IX 1, 231).Jung's intuition of the importance of animal is confirmed by recent research in several disciplines which prove the complementarity of humans and animals, and even the supremacy of animals over humans in performing certain tasks. According to animal scientist Temple Grandin, “animals have 'superhuman' skills: animals have animal genius" (287). She mentions migrating birds, gray squirrels burying hundreds of nuts and being able to recover them months later, forensic dogs, dogs who can predict seizures, and finally Clever Hans, the horse who was supposed to know how to count, add and answer mathematical questions, but who was actually able to perceive his questioner's facial alteration, indistinguishable to humans, when he was to stop "counting" by tapping with his hoof (289). Grandin also relates an experience in which rats performed more effectively than humans:

The rats and the humans had to look at a TV screen and press the lever anytime a dot appeared in the top half of the screen. The experimenter didn't tell the human subjects that's what they were supposed to do; they had to figure it out for themselves the same way the rats did. (265)

While humans were trying to figure out the rules of the experiment, the rats enthusiastically pressed the lever as often as they could, so "the rats ended up with lots more rewards than the humans" (266). Grandin further mentions that over millions of years, the human brain and the dog brain have changed in size, but each of them in a different, complementary way (306) ${ }^{3}$. So one might conclude that nature has determined that dog and man are to be allied and to complement each other.

Another "genius animal" is Oscar the Cat who "works" in a nursing home:

[S]ince he was adopted by staff members as a kitten, Oscar the Cat has had an uncanny ability to predict when residents are about to die. Thus far, he has presided over the deaths of more that 25 residents...His mere presence at the bedside is viewed by physicians and nursing home staff as an almost absolute indicator 
of impending death, allowing staff members to adequately notify families. . .

Oscar decides to head off to the west wing first, ... . Oscar continues down the hallway until he reaches its end and Room 310, The door is closed, so Oscar sits and waits. He has important business here. Twenty-five minutes later, the door finally opens, Oscar....makes his way into the room where there are two people. Mrs. T. is asleep...Sitting next to her is her daughter...Oscar takes no notice of the woman and leaps up onto the bed. He surveys Mrs. T. ..He sniffs the air, gives Mrs. T. one final look, then jumps off the bed and quickly leaves the room. Not today. Making his way back up the hallway, Oscar arrives at Room 313. The door is open, and he proceeds inside. Mrs. $\mathrm{K}$ is resting peacefully...Oscar jumps onto her bed and again sniffs the air. He pauses to consider the situation, and then turns around twice before curling up beside Mrs. K.

One hour passes. Oscar waits. A nurse walks into the room. She pauses to note Oscar's presence, concerned, she hurriedly leaves the room and ... begins to make phone calls. Within a half hour the family starts to arrive. . the priest is called to deliver last rites. And still, Oscar has not budged, instead purring and gently nuzzling Mrs K. A young grandson asks his mother, "What is the cat doing here?" The mother, fighting back tears, tells him, "He is here to help Grandma get to heaven." Thirty minutes later, Mrs. K. takes her last earthly breath. With this, Oscar sits up, looks around, then departs the room... On his way back to the charting area, Oscar passes a plaque mounted on the wall. On it is engraved a commendation from a local hospice agency: "For his compassionate hospice care, this plaque is awarded to Oscar the Cat."

For his work, Oscar is highly regarded by the physicians and staff . . and by families of the residents whom he serves. (328-329)

The research of Shephard, Midgley, Grandin and Dosa all questions the Aristotelian notion of the supremacy of humankind. Thus we understand why Guinefort, martyr, deserved to be canonized by humble peasants when the church was falling into the hands of the "Aristocrats of the Mind." 


\section{Stey}

While the Church was falling deeper and deeper under the possession of its shadow, Francis of Assisi (1181-1226) was trying to establish in the Church a counter-current, which theologian Leonardo Boff calls "conviviality (qd Linzey 65). Boff defines conviviality as the desire for a simple Church, mindful of the poor. We will remember that Saint Francis respected animals because humans and animals have the same origin. He called them "brothers and sisters" and was said to preach to the birds and once, according to the Occitan version of his life, he even asked them to refrain from singing while the monks were chanting the office. He was also said to have, by his preaching, convinced a wolf to stop eating villagers.

Mary Midgley further demonstrates how respect for animals, by negating the supremacy and autonomy of humankind, promotes equality, right and justice (74-75). This was certainly the message of Francis of Assisi, this early promoter of conviviality. Recently the medical profession had rediscovered the importance of conviviality, calling it "mindfulness." Mindfulness is taught at the Massachusetts School of Medicine and at the University of California in Los Angeles Institute for neuroscience and human behavior. Mindfulness is applied in psychotherapy, but also for stress and pain management in prisons and schools. "Mindfulness includes an affectionate, compassionate quality ... a sense of openhearted, friendly presence and interest," writes Daniel Siegel, director of the Los Angeles Center for Mindfulness (10).

Oscar the Cat and Guinefort are indeed practitioners of mindfulness. In summary, when Shepard writes "The convergence of love and death produces ... [humans' and animals'] shared identity in the cycle of transformation" (27), he seems to provide the symbolic meaning of Saint Guinefort's healing powers. In 1939, Jung wrote that it was urgent for society and for human beings to confront their own shadow, and to deepen their consciousness by integrating the opposites within their psyche. That was certainly already true in $13^{\text {th }}$ century France, and is still true today. Kevin Lu suggested during the 2006 Conference of the Jungian Society for Scholarly Studies that our $21^{\text {st }}$ century world badly needs an "ecopsychology," which would promote respect for the environment. Saint Guinefort, Oscar the Cat and many others advocate a "zoo-psychology," through which humans, by their respect for other animals, create a culture of peace and harmony, what Leonardo Boff calls a "civilization of conviviality" (qd Linzey 50) and Daniel Siegel's "Mindfulness." 


\section{Notes}

${ }^{1}$ Saint Guinefort, picture by Kent Roberts

2 The Albigensian or Cathar heresy defended a dualist belief, asserting that a good God could not have created a world laden with pain and suffering. This idea led to the conclusion that the devil, God's enemy -called Satanael-had created or, for some branches of Catharism, spoiled the physical world as well as the living bodies. The goal of the Cathars was thus to liberate their soul from their satanic body by letting their body die. Of course, in such a religious system, God could not have taken a human body. The Church saw this doctrine as extremely perversive since it negated the incarnation of Christ and His death, undermining the principle and the history of salvation.

The Valdenses or Waldenses were members of a sect which wanted to follow Christ in His poverty and and simplicity. They strongly opposed the Catholic Church because of its wealth and the greed of the clergy.

3 “ Maybe the most amazing new finding is that wolves didn't just teach us a lot of useful new behaviors, Wolves probably also changed the structure of our brains. Fossil records show that whenever a species becomes domesticated its brain gets smaller....the dog's brain shrank 10 to 30 percent. This probably happened because once humans started to take care of these animals, they no longer needed various brain functions in order to survive. . . Now, archaeologists have discovered that 10,000 years ago, just at the point when humans began to give their dogs formal burials, the human brain began to shrink too. It shrank by 10 percent, just like the dog's brain. And what's interesting is what part of the human brain shrank. In all of the domestic animals the forebrain, which holds the frontal lobes, and the corpus callosum, which is the connecting tissue between the two sides of the brain, shrank. But in humans, it was the midbrain, which handles emotions and sensory data and the olfactory bulbs, which handle smell, that got smaller while the corpus callosum and the forebrain stayed pretty much the same. Dog brains and human brains specialized: humans took over the planning and organizing tasks, and dogs took over the sensory tasks. Dogs and people coevolved and became even better partners, allies, and friends" (305-306) 